\title{
SIFAT KIMIA DAN ORGANOLEPTIK TELUR ASIN MEDIA ABU SERABUT KELAPA DENGAN PERBEDAAN LAMA PENYIMPANAN
}

\section{Chemical and Organoleptic Properties of Salted Eggs of Coconut Fiber Ash with Different Storage Period}

\author{
Onny Cahyasari ${ }^{1)}$, Wikanastri Hersoelistyorini ${ }^{2)}$, Nurrahman²) \\ ${ }^{1)}$ Mahasiswa Program Studi Teknologi Pangan, Fakultas Keperawatan dan Kesehatan \\ Universitas Muhammadiyah Semarang \\ ${ }^{2)}$ Staf Pengajar Program Studi Teknologi Pangan, Fakultas Keperawatan dan Kesehatan \\ Universitas Muhammadiyah Semarang \\ Korespondensi : onnycahyasari@gmail.com
}

\begin{abstract}
Eggs are easily damaged foodstuffs. Salting is one way to minimize damage and maintain storage. Salting generally uses $\mathrm{NaCl}$ salt for curing. In this study salting is done by utilizing the salt content of $\mathrm{KCl}$ in coconut fiber ash. This study aims to analyze the Total Volatile Nitrogen (TVN), rancidity (TBA) and organoleptic of salted eggs coconut fiber ash in during storage. This study used a Completely Randomized Design of One factor, with four different storage periods; 0 week storage, $1^{\text {st }}$ week storage, $2^{\text {nd }}$ week storage, and $3^{\text {rd }}$ week storage were analyzed TVN (Total Volatile Nitrogen), TBA (Thiobarbituric Acid) and organoleptic properties (bedonic quality). Data on TV N and TBA were analyzed using ANOV A while organoleptic was analyzed using Friedmen test. The highest result of TVN at $3^{\text {rd }}$ week was 1,902 $\mathrm{mg} / 100 \mathrm{~g}$ and the highest TB A result also at $3^{\text {rd }}$ week was $7.8 \mathrm{mg} / \mathrm{kg}$ of material. TV N and TB $A$ results were noticeable differences during storage. The longer stored then the TVN and TBA levels will increase. The organoleptic test produces salted eggs with color, aroma, texture that were not significantly different during storage and taste that was getting salty during storage. Based on the results of organoleptic test, salted eggs of coconut fiber ash were still acceptable until $3^{\text {rd }}$ week.
\end{abstract}

Keywords: salted egg, coconut fiber ash, TVN, TBA, organoleptic

\section{PENDAHULUAN}

Telur merupakan salah satu bahan makanan sumber protein hewani yang memiliki manfaat bagi pertumbuhan makhluk hidup. Pangan asal hewani ini memiliki nilai gizi yang tinggi, terutama kandungan protein dan lemak. Protein telur terdiri dari asam amino esensial yang lengkap sehingga menjadi patokan untuk menentukan mutu protein dari bahan pangan lain (Koswara, 2009).
Salah satu sifat telur yaitu mudah mengalami kerusakan. Kerusakan pada telur dapat terjadi dalam bentuk kerusakan fisik, kerusakan kimiawi, atau kerusakan akibat mikroorganisme. Pengawetan untuk memperkecil kerusakan dan mempertahankan mutu telur telah banyak dilakukan, seperti pengasinan, penyamakan dengan bahan nabati, perendaman dalam larutan kapur, dan metode penyimpanan dingin (Koswara, 2009). 
Pengawetan telur dengan cara pengasinan telah dikenal oleh masyarakat. Pengasinan pada umumnya dilakukan dengan cara merendam telur dalam larutan garam $(\mathrm{NaCl})$ atau memeram telur dalam adonan yang terdiri dari batu bata, abu, dan garam. Penelitian Fahlepi (2007) dalam Sari (2008) menyebutkan ada alternatif pengasinan telur tanpa penggunaan $\mathrm{NaCl}$ yaitu dengan pemanfaatan abu serabut kelapa.

Serabut kelapa merupakan hasil samping dan bagian terbesar dari buah kelapa yaitu sebesar 35\% dari bobot buah kelapa (Hartono, 2013). Serabut kelapa banyak dimanfaatkan sebagai bahan bakar, sapu, dan produk produk kesenian. Pemanfaatan limbah serabut kelapa sebagai bahan bakar akan menghasilkan abu serabut kelapa yang dapat dijadikan alternatif untuk pengasinan telur.

Serabut kelapa mengandung unsur Magnesium $(\mathrm{Mg})$ dan Kalium (K) yang dapat dimanfaatkan untuk pengasinan telur tanpa penambahan garam (Fahlepi 2007 dalam Sari, 2008). Penelitian Prihantari et al. (2010) menyebutkan bahwa pemeraman telur dengan abu serabut kelapa selama 1 minggu merupakan waktu yang optimal untuk daya simpan, organoleptik (tingkat kesukaan), dan kadar kalsium telur asin. Selain itu, penelitian Randa (2009) menyebutkan bahwa pemeraman 10 hari merupakan pemeraman yang paling disukai panelis. Begitu juga penelitian Purfianti (2013) yang menyatakan bahwa telur asin serabut kelapa yang diperam selama 7 hari dan dikukus selama 20 menit memiliki kadar protein dan lemak terbaik.

Pengasinan merupakan salah satu upaya untuk memperpanjang masa simpan. Menurut Koswara (2009) konsentrasi garam yang diberikan pada saat pemeraman telur asin mempengaruhi daya simpan telur asin. Produk yang disimpan dalam jangka waktu lama akan mengalami penurunan kualitas baik secara fisik, kimia, maupun mikrobiologi. Semakin lama penyimpanan telur asin maka kadar proteinnya akan semakin berkurang (Safrullah et al., 2014). Menurut Ratnasari (2014) bahan makanan akan mengalami penurunan mutu protein yang signifikan jika disimpan dalam waktu yang lama. Penurunan tersebut ditunjukkan dengan meningkatnya 
angka TVN (Total Volatil Nitrogen) karena adanya degradasi protein akibat aktivitas enzim dan bakteri. Sedangkan penurunan mutu lemak ditunjukkan dengan meningkatnya angka TBA (Thiobarbituric Acid) akibat reaksi oksidasi yang menghasilkan senyawa - senyawa radikal bebas kemudian timbul bau tengik pada lemak.

\section{METODOLOGI}

Penelitian ini menggunakan Rancangan Acak Lengkap satu faktor, dengan empat perbedaan lama penyimpanan ; penyimpanan minggu ke $0,1,2$, dan 3 selanjutnya dianalisis TVN (Total Volatile Nitrogen), TBA (Thiobarbituric Acid) dan sifat organoleptik (mutu hedonik).

\section{Bahan}

Bahan utama dalam pembuatan telur asin yaitu telur itik yang diambil dari daerah Temanggung dengan berat 60-70 gram, serabut kelapa yang diambil dari limbah serabut kelapa di daerah Ungaran. Bahan kimia yang digunakan terdiri atas $\mathrm{MgO}, \mathrm{HCl}$ 0,01 N, $\mathrm{H}_{3} \mathrm{BO}_{3}$, TBA, $\mathrm{HCl} 4 \mathrm{M}$, dan aquades.

\section{Pembuatan Telur Asin}

Telur bebek yang telah dipilih, diamplas kemudian dibungkus dengan adonan satu persatu secara merata sekeliling permukaan telur dengan perbandingan $2: 1$ (berat adonan : berat telur). Telur diperam dalam ember plastik bertutup selama 1 minggu, selanjutnya telur direbus sampai matang ( \pm 30 menit).

\section{Penyimpanan Telur}

Telur asin yang telah dibuat disimpan pada suhu ruang $(0,1,2,3$ minggu). Pada setiap minggu dianalisa TVN, TBA, dan sifat organoleptik.

\section{Analisa Data}

Untuk mengetahui pengaruh lama penyimpanan terhadap TVN dan TBA menggunakan uji ANOVA, jika ada pengaruh $(\mathrm{p}<0,05)$ maka dilanjutkan Post Hoc Test menggunakan Tukey. Sedangkan uji organoleptik menggunakan uji Friedman dan apabila ada perbedaan $(\mathrm{p}<0,05)$ maka dilanjutkan uji Wilcoxon.

\section{HASIL DAN PEMBAHASAN}

\section{Kadar TVN (Total Volatil Nitrogen)}

Telur asin pada penyimpanan 0 minggu menunjukkan kadar TVN yang paling 
rendah yaitu sebesar $0.393 \mathrm{mg} / 100 \mathrm{~g}$ karena

telur asin baru selesai diperam dan matang sehingga belum banyak TVN yang terbentuk.

Menurut Ozogul et al (2000) kadar TVN

sudah terbentuk walaupun bahan pangan (ikan) dalam keadaan segar.
Hasil analisis statistik menunjukkan lama penyimpanan berpengaruh sangat nyata terhadap kadar TVN telur asin $(\mathrm{p}=0.000)$. Uji Tukey dengan taraf kepercayaan 95\% menunjukkan bahwa penyimpanan minggu ke 3 mempunyai kadar TVN paling tinggi

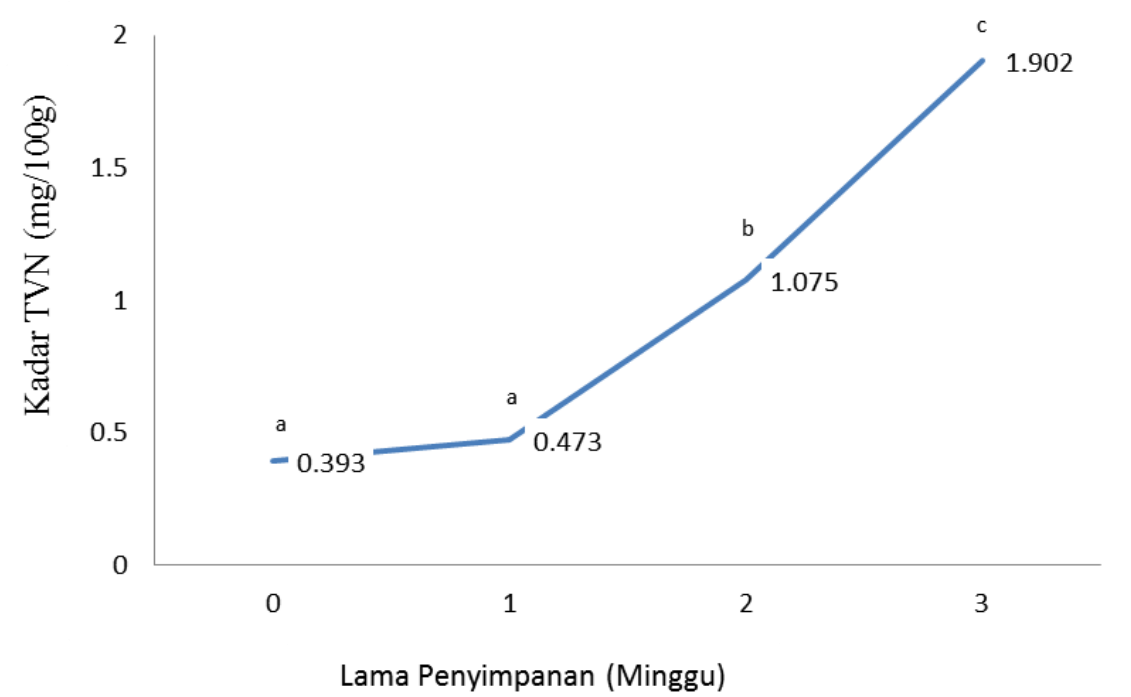

Gambar 1. Grafik pengaruh lama penyimpanan terhadap kadar TVN ket : huruf yang sama menunjukkan tidak berbeda nyata

Selama penyimpanan terjadi proses pemecahan protein yang menghasilkan senyawa alkohol dan gas seperti $\mathrm{CO}_{2}, \mathrm{CH}_{4}$, $\mathrm{H}_{2}, \mathrm{NH}_{3}$ (Fardiaz, 1992). Peningkatan kadar TVN disebabkan oleh aktivitas enzim dan mikroorganisme yang memecah protein menjadi senyawa sederhana yang mengandung basa menguap seperti $\mathrm{NH}_{3}$ (Santoso et al, 2008). Hal ini menunjukkan bahwa kadar TVN semakin meningkat seiring dengan lama penyimpanan. dan berbeda nyata $(p=0.000)$ dengan penyimpanan minggu ke 0,1 dan 2 . Kadar TVN tidak berbeda nyata $(\mathrm{p}=0.838)$ pada penyimpanan minggu ke 0 dengan penyimpanan minggu ke 1 . Hal ini karena adanya kandungan garam $\mathrm{KCl}$ pada telur yang bersumber dari abu serabut kelapa yang dapat menahan aktivitas enzim dan mikroorganisme dalam merombak protein menjadi senyawa yang lebih sederhana. Menurut Ratnasari et al (2014) penambahan 
larutan garam dapat menghambat

masih memiliki nilai TVN yang rendah

terbentuknya senyawa volatil karena garam sampai penyimpanan minggu ke 3 .

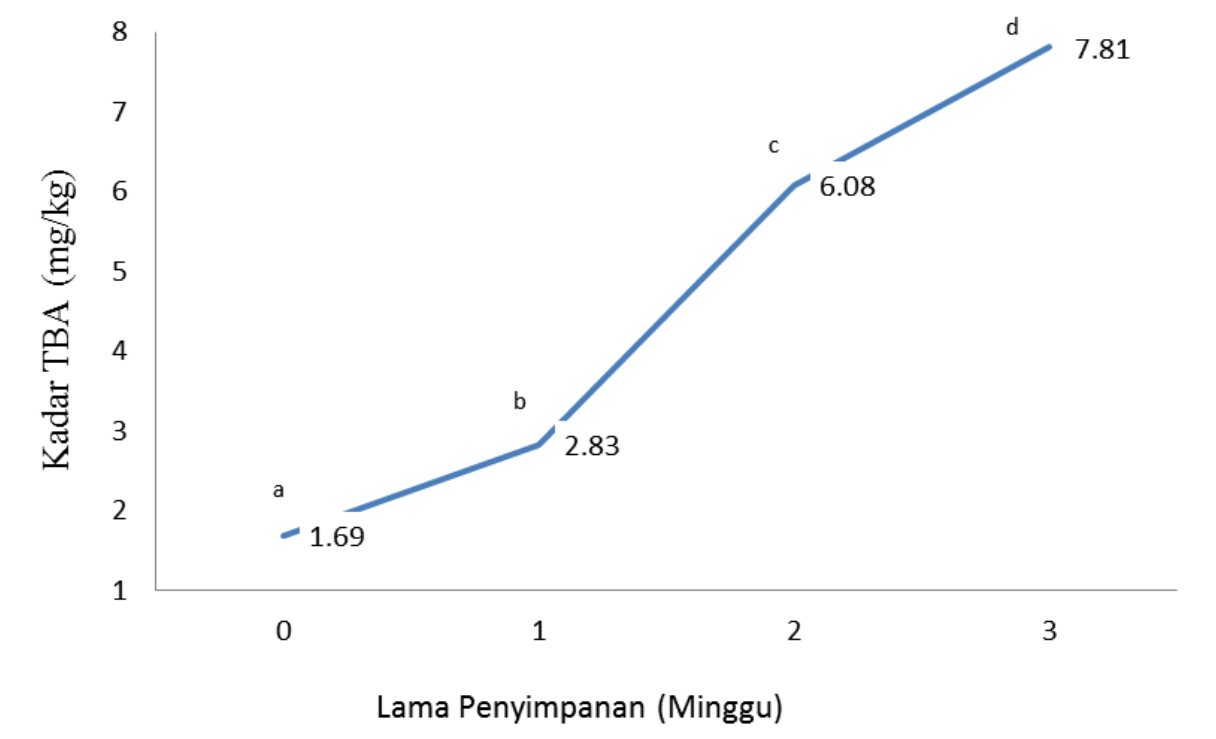

Gambar 2. Grafik pengaruh lama penyimpanan terhadap kadar TBA ket : huruf yang sama menunjukkan tidak berbeda nyata

memiliki tekanan osmotik tinggi yang dapat mengganggu kegiatan bakteri pembusuk penyebab naiknya nilai TVN.

Kadar nilai TVN sumber protein hewani seperti ikan laut berkisar antara 30-35 $\mathrm{mg} / 100 \mathrm{~g}$, ikan air tawar $18-25 \mathrm{mg} / 100 \mathrm{~g}$ (Zaitsev et al 1969 dalam Petalia et al, 2017) sedangkan ikan yang telah dikeringkan dan digarami memiliki nilai TVN antara $100-120$ mg/100g (SNI, 2009). Pada penelitian ini, kadar TVN telur asin serabut kelapa paling tinggi sebesar 1,902 mg/100g. Hal ini menunjukkan bahwa telur asin serabut kelapa

\section{Kadar TBA (Thiobarbituric Acid)}

Hasil analisis sidik ragam menunjukkan bahwa lama penyimpanan berpengaruh nyata $(p=0.000)$ terhadap nilai TBA. Hasil uji Tukey menunjukkan bahwa nilai TBA berbeda nyata $(p=0.000)$ pada setiap penyimpanan. Hal ini karena adanya aktivitas enzim dan mikroba. Semua enzim yang masuk dalam golongan lipase mampu menghidrolisa trigliserida menjadi asam lemak bebas dan gliserol. Kerusakan oksidatif pada makanan berlemak menjadi masalah penting karena dapat menurunkan mutu bahan pangan (Anonim, 2012). 
Faktor lain seperti pengolahan, proses pemanasan dan waktu penyimpanan dapat memicu penguraian lemak yang mengakibatkan oksidasi lemak. Kerusakan lemak tersebut dapat menimbulkan bau dan rasa tengik pada bahan pangan. Kerusakan lemak dapat disebabkan karena oksidasi asam lemak tidak jenuh. Proses oksidasi dapat terjadi pada suhu ruang maupun pengolahan suhu tinggi (Ubba, 2015).

Ketengikan pada daging ayam terdeteksi jika nilai TBA $>1 \mathrm{mg} / \mathrm{kg}$ sampel (Kolsarici et al, 2010 dalam Saputri, 2011). Menurut Gunsel et al (2011) dalam Saputri (2011) ikan masih dikatakan baik jika TBA <5 $\mathrm{mg} / \mathrm{kg}$ sampel. Pada penelitian ini, kadar TBA pada penyimpanan minggu ke 0,1,2,3 berturut - turur sebesar 1,69mg/kg, 2,83 $\mathrm{mg} / \mathrm{kg}, \quad 6,08 \mathrm{mg} / \mathrm{kg}, \quad 7,81 \mathrm{mg} / \mathrm{kg}$. Hal ini menunjukkan bahwa peningkatan TBA pada telur asin serabut kelapa cukup tinggi bila dibandingkan dengan sumber protein hewani lainnya.

\section{Sifat Organoleptik}

\section{Warna}

Gambar 3 menunjukkan bahwa warna pada telur asin serabut kelapa masuk dalam kategori agak cerah pada setiap penyimpanan (skor=3). Hal ini dimungkinkan karena kandungan mineral hanya bersumber dari abu serabut kelapa sehingga warna telur asin tidak masuk kategori gelap. Seperti yang diungkapkan oleh Prihantari et al (2010) bahwa warna pada telur asin dipengaruhi oleh kandungan mineral dari media pemeraman dan lama pemeraman.

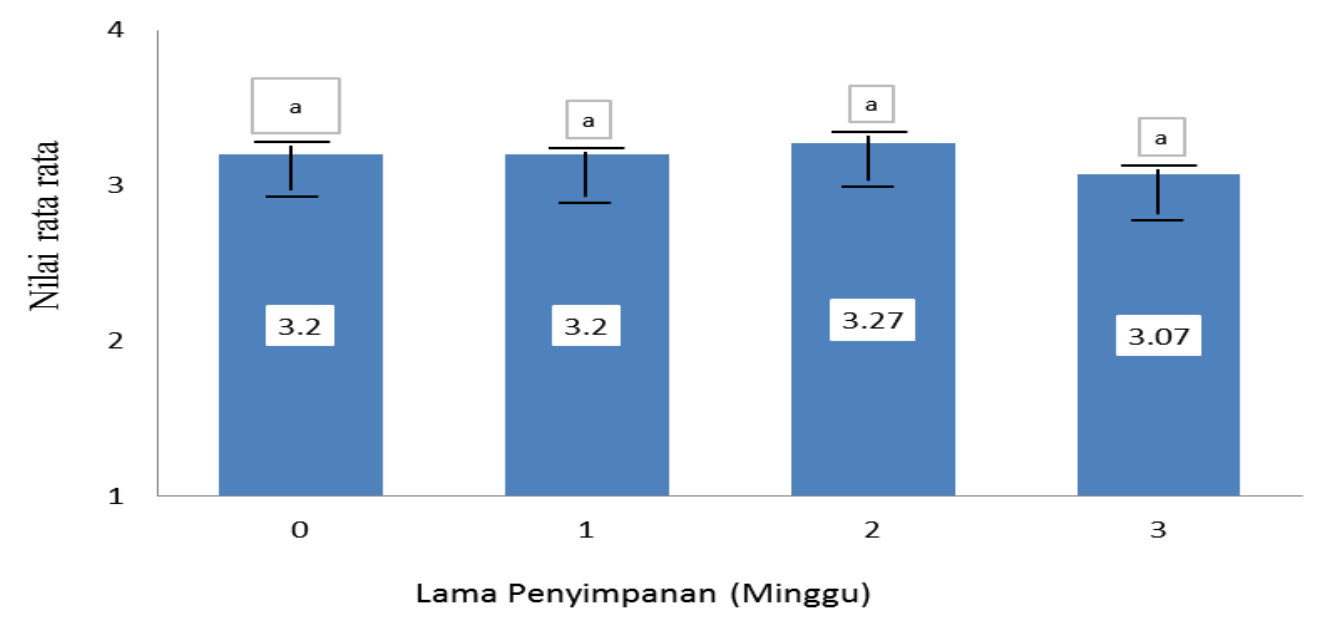

Gambar 3. Rata rata nilai mutu hedonik warna telur asin ket : huruf yang sama menunjukkan tidak berbeda nyata 
Semakin banyak media yang digunakan dalam

pemeraman telur dan semakin lama waktu

pemeraman yang dilakukan maka warna telur
Telur asin yang diasinkan menggunakan media abu serabut kelapa memiliki aroma agak segar (skor=3). Selama

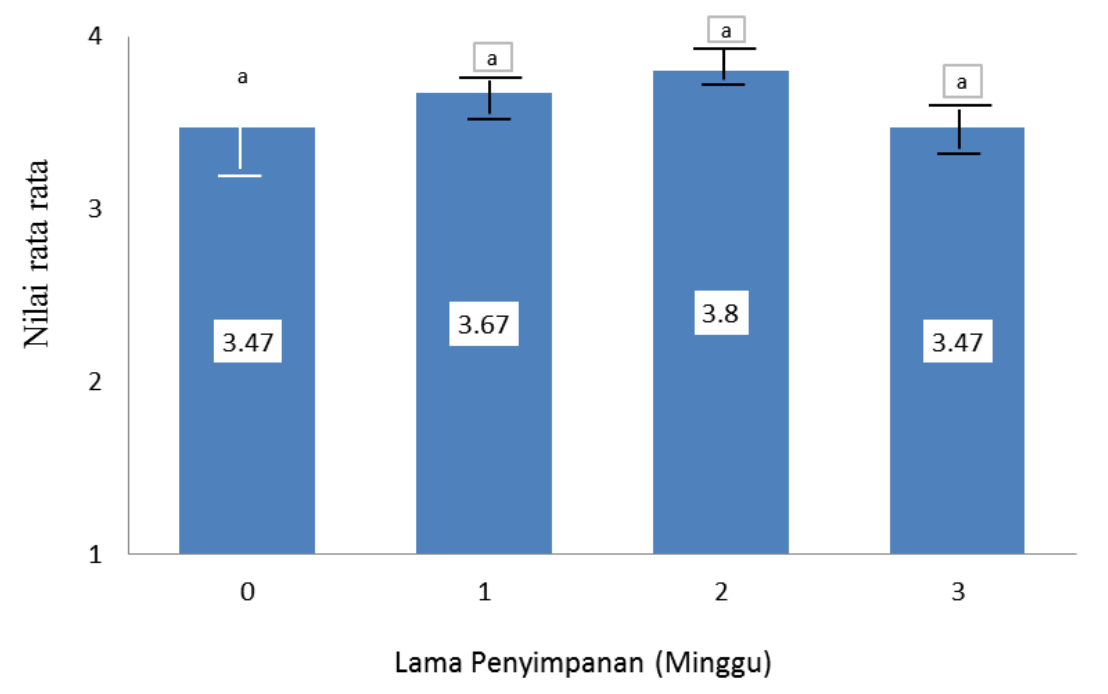

Gambar 4. Rata rata nilai mutu hedonik aroma telur asin. ket : huruf yang sama menunjukkan tidak berbeda nyata

akan semakin gelap. Gambar 3 juga menunjukkan bahwa skor telur asin mengalami penurunan pada minggu ke 3 . Hal ini dimungkinkn karena semakin meningkatnya nilai TVN dan TBA yang mempengaruhi warna telur asin.

Hasil analisis statistik juga menunjukkan bahwa warna pada setiap penyimpanan tidak berbeda nyata $(\mathrm{p}=0.817)$. Hal ini karena pengasianan merupakan cara pengawetan telur untuk mempertahankan mutu telur sehingga selama penyimpanan berlangsung warna telur asin tidak berubah.

\section{Aroma}

penyimpanan berlangsung telur asin masih memiliki aroma yang sama (agak segar) namun pada minggu ke 3 skor telur asin mengalami penurunan. Hal ini dimungkinkan karena aroma amoniak pada telur asin mulai tercium.

Selaras dengan hasil TVN dan TBA yang dianalisis bahwa semakin lama penyimpanan maka nilai TVN dan TBA semakin meningkat. Nilai TVN yang tinggi menjadi salah satu parameter semakin banyak terbentuknya basa yang bersifat volatil seperti amoniak dan nilai TBA yang tinggi menimbulkan bau tengik pada bahan pangan. 
Hasil analisis statistik aroma telur asin selama penyimpanan tidak berbeda nyata $(p=0.316)$. Pengasinan merupakan salah satu metode untuk mengawetkan telur asin. Garam yang terkandung pada telur asin mampu mempertahankan cita rasa telur asin (Koswara, 2009). Selaras dengan penelitian ini bahwa aroma telur asin serabut kelapa masih sama dan tidak berbau busuk selama 3 minggu penyimpanan.

\section{Rasa}

Hasil dari penilaian organoleptik rasa telur asin disajikan pada Gambar 5. Gambar 5 menunjukkan bahwa semakin lama penyimpanan telur asin semakin terasa asin. Hal tersebut dapat dilihat pada skor yang diperoleh pada minggu ke 0 sebesar 1,67 (tidak asin) sampai minggu ke 3 sebesar 2,47 (agak asin). Hasil analisis statistik juga menunjukkan bahwa lama penyimpanan berpengaruh nyata $(p=0.002)$ terhadap rasa telur asin.

Uji lanjut Wilcoxon menunjukkan nilai TBA berbeda nyata pada minggu ke 2 $(p=0.046)$ dan $3(p=0.008)$. Hal tersebut kemungkinan karena lambatnya penetrasi garam $\mathrm{KCl}$ ke dalam telur. Seperti yang diungkapkan oleh Koswara (2009) bahwa pengasinan merupakan proses penetrasi garam ke dalam bahan yang diasin dengan cara difusi. Laju difusi tergantung perbedaan tekanan osmosis antara isi telur dan kandungan garam dalam adonan. Makin besar perbedaannya, makin cepat laju difusi yang terjadi. Pada penelitian ini konsentrasi $\mathrm{KCl}$ hanya bergantung dari abu serabut kelapa saja

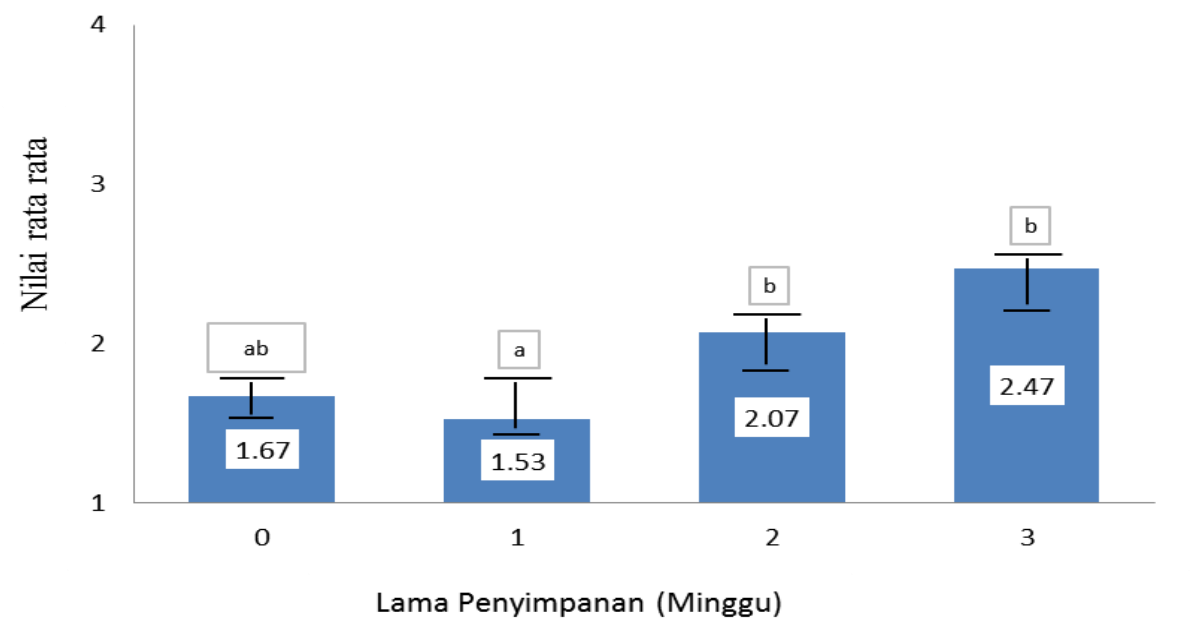

Gambar 5. Rata rata nilai mutu hedonik rasa telur asin. ket : huruf yang sama menunjukkan tidak berbeda nyata 
sehingga proses pengasinan menjadi lebih lambat daripada menggunakan garam.

Hal lain yang menyebabkan rasa asin semakin bertambah yaitu hilangnya kadar air telur selama proses penyimpanan berlangsung. Selama penyimpanan kandungan air dalam telur akan menurun sehingga konsentrasi garam dalam telur menjadi lebih pekat. Koswara (2009) mengungkapkan bahwa telur yang diasin mengalami difusi air serta penguapan uap air dan gas-gas keluar dari dalam telur. Hal tersebut juga menyebabkan berat telur yang telah diasin mengalami penurunan.

\section{Tekstur}

Tekstur telur asin serabut kelapa masuk dalam kategori agak kenyal (skor=3).
Hasil analisis statistik menunjukkan bahwa tektur telur asin tidak berbeda nyata $(p=0.892)$ selama penyimpanan. Sifat telur yang terkoagulasi oleh garam dan panas menjadikan tekstur telur asin menjadi kenyal setelah proses pengasinan. Koagulasi pada telur dapat terjadi karena panas, garam, basa, asam atau pereaksi lain (misal urea). Koagulasi atau penggumpalan adalah perubahan struktur protein telur yang mengakibatkan peningkatan kekentalan dan hilangnya kelarutan, atau dapat juga berarti perubahan bentuk dari cairan (sol) menjadi bentuk padat atau semi padat (gel) (Koswara, 2009).

Koagulasi oleh panas terjadi akibat reaksi antara protein dan air yang diikuti

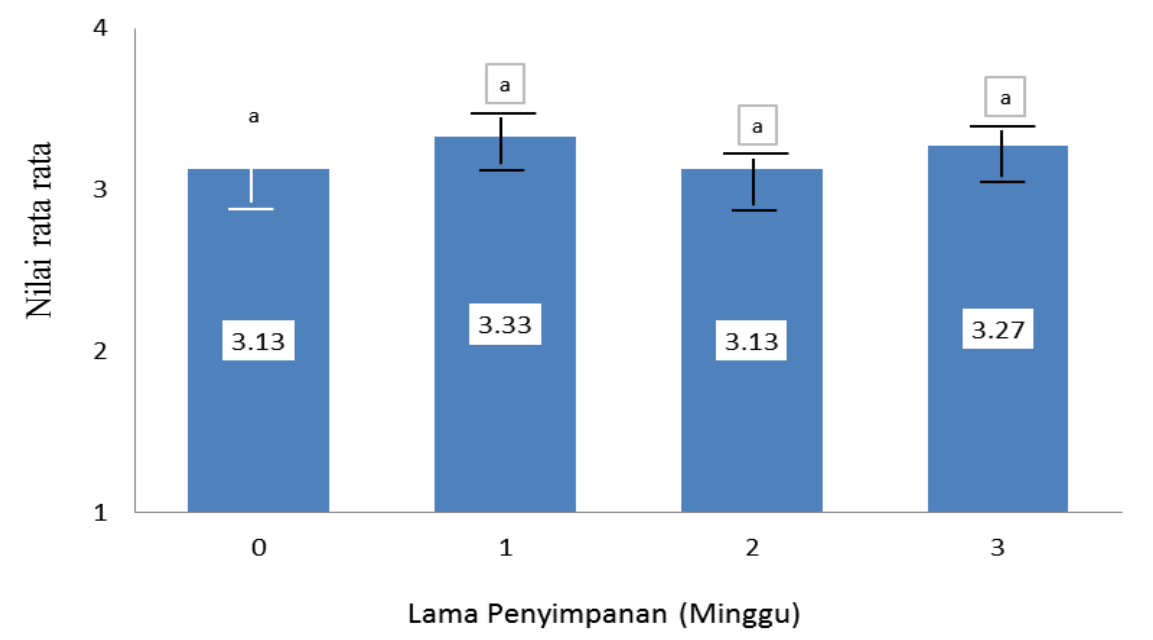

Gambar 6. Rata rata nilai mutu hedonik tekstur telur asin ket : huruf yang sama menunjukkan tidak berbeda nyata 
dengan penggumpalan protein (karena

ikatan-ikatan antar molekul). Putih telur ayam

akan terkoagulasi pada suhu $62{ }^{\circ} \mathrm{C}$, sedangkan

kuning telurnya terkoagulasi pada $65{ }^{\circ} \mathrm{C}$.

Putih telur bebek terkoagulasi pada suhu yang lebih rendah, yaitu $65{ }^{\circ} \mathrm{C}$ setelah 10 menit pemanasan. Koagulasi karena garam menyebabkan protein berubah menjadi curd (semacam gumpalan tahu) (Koswara, 2009).

\section{Rekapitulasi Data}

Tabel 1. Rekapitulasi hasil penelitian

\begin{tabular}{|c|c|c|c|c|c|}
\hline \multirow{2}{*}{\multicolumn{2}{|c|}{ Analisis }} & \multicolumn{4}{|c|}{ Lama penyimpanan (Minggu) } \\
\hline & & 0 & 1 & 2 & 3 \\
\hline \multicolumn{2}{|c|}{ TVN (mg/100g) } & $0.393^{\mathrm{a}}$ & $0.473^{\mathrm{a}}$ & $1.075^{\mathrm{b}}$ & $1.902^{c}$ \\
\hline \multicolumn{2}{|c|}{$\mathrm{TBA}(\mathrm{mg} / \mathrm{kg})$} & $1.69^{\mathrm{a}}$ & $2.83^{\mathrm{b}}$ & $6.08^{c}$ & $7.81^{\mathrm{d}}$ \\
\hline \multirow{8}{*}{ Organoleptik } & \multirow{2}{*}{ Warna } & $3.2^{\mathrm{a}}$ & $3.2^{\mathrm{a}}$ & $3.27^{\mathrm{a}}$ & $3.07^{\mathrm{a}}$ \\
\hline & & Agak cerah & Agak cerah & Agak cerah & Agak cerah \\
\hline & \multirow{2}{*}{ Aroma } & $3.47^{\mathrm{a}}$ & $3.67^{\mathrm{a}}$ & $3.8^{\mathrm{a}}$ & $3.47^{\mathrm{a}}$ \\
\hline & & Agak segar & Agak segar & Agak segar & Agak segar \\
\hline & \multirow{2}{*}{ Rasa } & $1.67^{\mathrm{ab}}$ & $1.53^{\mathrm{a}}$ & $2.07^{\mathrm{b}}$ & $2.47^{\mathrm{b}}$ \\
\hline & & Tidak asin & Tidak asin & Agak asin & Agak asin \\
\hline & \multirow{2}{*}{ Tekstur } & $3.13^{\mathrm{a}}$ & $3.33^{\mathrm{a}}$ & $3.13^{\mathrm{a}}$ & $3.27^{\mathrm{a}}$ \\
\hline & & Agak kenyal & Agak kenyal & Agak kenyal & Agak kenyal \\
\hline
\end{tabular}

Tabel 1 menunjukkan bahwa semakin lama penyimpanan maka kadar TVN dan TBA semakin meningkat dan organoleptik (warna dan aroma) mengalami penurunan pada minggu ke 3. Hal ini diduga karena kadar TVN dan TBA yang semakin meningkat sehingga berpengaruh pada warna dan aroma telur asin.

Kadar TVN dan TBA telur asin memang mengalami kenaikan pada setiap minggunya, tapi secara organoleptik telur asin abu serabut kelapa masih bisa diterima hingga minggu ke 3.

\section{KESIMPULAN}

Pada penelitian ini dapat diambil kesimpulan bahwa tidak ada pengaruh penyimpanan terhadap kadar TVN telur asin media serabut kelapa pada penyimpanan 1 minggu, tetapi berpengaruh nyata terhadap penyimpanan 2 dan 3 minggu. Penyimpanan telur asin serabut kelapa juga berpengaruh sangat nyata terhadap nilai TBA. Data yang didapatkan menunjukkan bahwa semakin lama penyimpanan maka kadar TVN dan TBA akan semakin meningkat. 
Hasil analisis organoleptik mutu

hedonik menunjukkan bahwa penyimpanan telur asin abu serabut kelapa tidak berpengaruh terhadap warna, aroma, dan tekstur, tetapi berpengaruh pada rasa telur asin. Semakin lama penyimpanan telur asin serabut kelapa maka rasa telur asin akan semakin asin.

\section{DAFTAR PUSTAKA}

Angela, G.C., Feny M., Grace S. 2015. Kajian Mutu Ikan Cakalang (Katsuwonus Pelamis., L.) Asap Dari Tempat Pengasapan Desa Girian Atas Yang Dikemas Vakum dan Non Vakum Selama Penyimpanan Dingin. Jurnal Media Teknologi Hasil Perikanan : Vol 3 No.2

Antonacopoulos, N. dan Vyncke, W. 1989. Determination Of Volatil Basic Nitrogen In Fish: A Third Colaborative Study By THE WEST EUROPEAN FISH TEHNOLOGIST ASSOIATION (WEFTA). Zeitschrift Fur Lebensmitteluntersucung Und Forschung A 189(4): 309 - 316.

Apriyantono, Anton. 1986. Penuntun Praktikum Analisa Pangan. IPB, Bogor.

Fardiaz S. 1992. Polusi Air dan Polusi Udara. Bogor : Pusat Antar Universitas Pangan dan Gizi, IPB

Haryoto.2010. Telur Asin. Kanisius, Yogyakarta.

Koswara, S 2009. Teknologi Pengolaban Telur. eBookPangan.com, hal 19.
LIPTAN (Lembar Informasi Pertanian). 2005. Pembuatan Telur Asin. BPTP Yogyakarta : Departemen Pertanian.

Novia, D., Indri J., dan Sri M. 2009. Peningkatan Gizi dan Ekonomi Masyarakat Kelurahan Koto Luar Kecamatan Paub Padang Melalui Pelatihan Pembuatan Telur Asin Rendab Sodium. Warta Pengabdian Andalas Volume XV nomor 22.

Nurrahman, K. 2011. Uji Protein dan Kalsium Pada Telur Asin Hasil Pengasinan Menggunakan Abu Pelepab Kelapa dan Perendaman Dalam Larutan Teh Berbagai Konsentrasi. Skripsi IAIN Walisongo, Semarang.

Ozogul F, Ozogul Y.2000. Comparison Of Methods Used For Determination Of Total Volatile Base Nitrogen (TVBN) In Rainbow Trout. Turk J.Zool 24 : 113120

Petalia, P., Elisa J., Linda ML. 2016. Pengaruh Berbagai Jenis Asam Jeruk Terhadap Perubahan Mutu Ikan Mas Naniura Selama Waktu Display. Jutnal Rekayasa Pangan dan Peternakan Fakultas Pertanian USU, Medan.

Prihantari, M., Agus W., dan Tri S. 2010. Pengarub Lama Perendaman Abu Pelepah Kelapa Terhadap Sifat Fisik, Organoleptik, Daya Simpan dan Kadar Kalsium Telur Asin. Skripsi Politeknik Kesehatan Yogyakarta, Yogyakarta.

Puspianti, E. 2013. Uji Organoleptik Pada Telur Yang Diasinkan Dengan Abu Pelepah Kelapa dan Dimasak Dengan Cara Kukus dan Asap. Skripsi Universitas Muhammadiyah Surakarta, Surakarta.

Randa, ECCG. 2009. Kadar Protein, Kadar Lemak dan Nilai Organoleptik Telur Asin Pada Beberapa Tingkat Pemeraman Dengan Abu Limbah Sabut Kelapa. Skripsi Universitas Andalas, Padang. 
Ratnasari, Z., Ace B., Agus S. 2014. Penggunaan Garam, Sukrosa dan Asam Sitrat Konsentrasi Rendah Untuk Mempertahankan Mutu Fillet Ikan gabus (Channa Striata) yang Disimpan Pada Subu $4^{\circ} \mathrm{C}$. Fishtech : Vol III No.1

Sari, SK.2008. Uji Vitamin dan Mineral Pada Telur Asin Hasil Pengasinan Tanpa Garam Dapur. Skripsi Universitas Muhammadiyah Surakarta, Surakarta.

Sarmilah. 2015. Bentuk Kerusakan Makanan Pada Telur. Makalah : Politeknik Kesehatan Kemenkes Makasar.

Yosi, F., Nurul H., Jurlinda, Meisiji LS. 2016. Kualitas Fisik Telur Asin Itik Pegagan yang Diproses Dengan Menggunakan Abu Pelepab Kelapa Sawit dan Asap Cair. Buletin Peternakan Vol.40 6674, Universitas Sriwijaya.

Yulianto, Tri. 2011. Pengarub Penambahan Ekstrak Daun Teh Hijau, Ekstrak Daun Jambu Biji, dan Ekstrak Daun Salam Pada Pembuatan Telur Asin Rebus Terhadap Total Bakteri Selama Penyimpanan. Skripsi Universitas Sebelas Maret. Surakarta. 